\title{
Tree Health Assessment of Lauraceae Collections in Bogor Botanic Gardens using Forest Health Monitoring Method
}

Rizmoon Nurul Zulkarnaen*, Fitri Fatma Wardani, Prima Wahyu Kusuma Hutabarat, Irfan Martiansyah, Muhammad Rifqi Hariri

Research Center for Plant Conservation and Botanic Gardens, Indonesian Institute of Sciences (LIPI). Jl. Ir. H. Juanda No. 13 Paledang, Bogor, 16122, West Java, Indonesia

* Corresponding author. E-mail address: rizmoon.zulkar@gmail.com

\section{ARTICLE HISTORY:}

Received: 1 March 2021

Peer review completed: 23 March 2021 Received in revised form: 5 April 2021 Accepted: 14 September 2021

\section{KEYWORDS:}

Botanic gardens Forest Health Monitoring Lauraceae Tree health

(C) 2021 The Author(s). Published by Department of Forestry, Faculty of Agriculture, University of Lampung in collaboration with Indonesia Network for Agroforestry Education (INAFE).

This is an open access article under the CC BY-NC license:

https://creativecommons.org/licenses/by$\mathrm{nc} / 4.0 /$

\begin{abstract}
Bogor Botanic Gardens (BBG) is an ex-situ plant conservation area with thousands of plant collections. The trees of the Lauraceae in BBG experienced the highest number of deaths among other families. However most of them were categorized as young planting years ( $0-15$ years). A tree health monitoring in the Lauraceae needs to be conducted to provide an overview, trend, and value of the level of damage. Forest Health Monitoring (FHM) method was carried out on two plots consisting of 149 trees. FHM can identify the types and levels of damage through monitoring and recording a series of tree damage. The results showed that among 149 trees, with 103 healthy, 9 lightly damaged, 10 moderately damaged, 15 heavily damaged, and 12 dead. The damage was primarily found in the stem (63 trees), the crown branch (51 trees), and the roots (13 trees). The severity of the damage was mainly at a mild level (0-19\%). The cause of the damage is discussed. Further observations and frequent monitoring of the health of the Lauraceae need to be conducted by management to reduce the number of dead collections of the family.
\end{abstract}

\section{Introduction}

The existence of a botanical garden and plant collection in it has a significant value both from an economic, historical, and scientific point of view. A botanical garden is an ex-situ plant conservation area where the collection is documented and organized according to taxonomic, bioregional, thematic classification patterns, or a combination of the tree (President Regulation No 93 of 2011). Bogor Botanic Gardens (BBG), one of the leading sectors in botanical research and plant conservation activities, has maintained more than 12,000 plant collections (Ariati et al. 2019). Most of the plant collections in BBG are dominated by tree habitus. Therefore, their management and maintenance have their challenges (Ramdhani and Fatimah 2016).

Tree health of BBG collections decreases naturally with increasing the age of the plants. The increasing age of trees increases the risk of damage and death of the collections (Setyanti et al. 2020). Tree death generally begins with physiological damage due to biotic and abiotic factors arising from adverse reactions between plants and their environment (Tsani and Safe'i 2018). Damage can be seen through symptoms that appear, such as abnormal leaves, branches, and stems, and through signs of plant-disturbing organisms (Pribadi 2010; Tsani and Safe'i 2018). The 
damages that are not immediately detected and addressed will cause the tree to fall or die, which means economical and social losses (Abimanyu et al. 2019; Pertiwi et al. 2019).

The number of tree death cases in BBG has increased yearly (Setyanti et al. 2020), reaching 3.197 tree death cases of 113 tree families. The Lauraceae is one of the tree-habitus families with the most significant number of death cases compared to other tree collections (Setyanti et al. 2020). Therefore, it is necessary to detect and monitor the tree health of the Lauraceae in BBG, such as using the Forest Monitoring Health (FHM) approach (Mangold 1997). FHM is one of the progressive methods or procedures in assessing tree health and has been widely practiced globally (Pertiwi et al. 2019; Susilowati et al. 2018). The FHM method could identify the type of damage and disturbance through a series of monitoring and recording of tree damage (Abimanyu et al. 2019). This study aims to assess the level of damage to Lauraceae collections in BBG. This study is expected to be the basis for maintaining Lauraceae collections so that the handling of collection damage can be improved and the death rate of Lauraceae can be reduced.

\section{Materials and Methods}

\subsection{Research Location}

This study was conducted in February 2020 in Bogor Botanic Gardens (BBG). The Lauraceae collections were randomly distributed in the BBG, but two plots were designated explicitly as plots of the Lauraceae collection, which are plots XX.A and XX.B (Fig. 1). The number of Lauraceae has observed 149 trees in the two plots (Table 1). The method used followed the procedure of Forest Health Monitoring (FHM) (Mangold 1997). Detection of tree health conditions using the FHM method will provide data on the level of tree damage based on the type, location, and severity of damage (Mangold 1997; Susilowati et al. 2018).

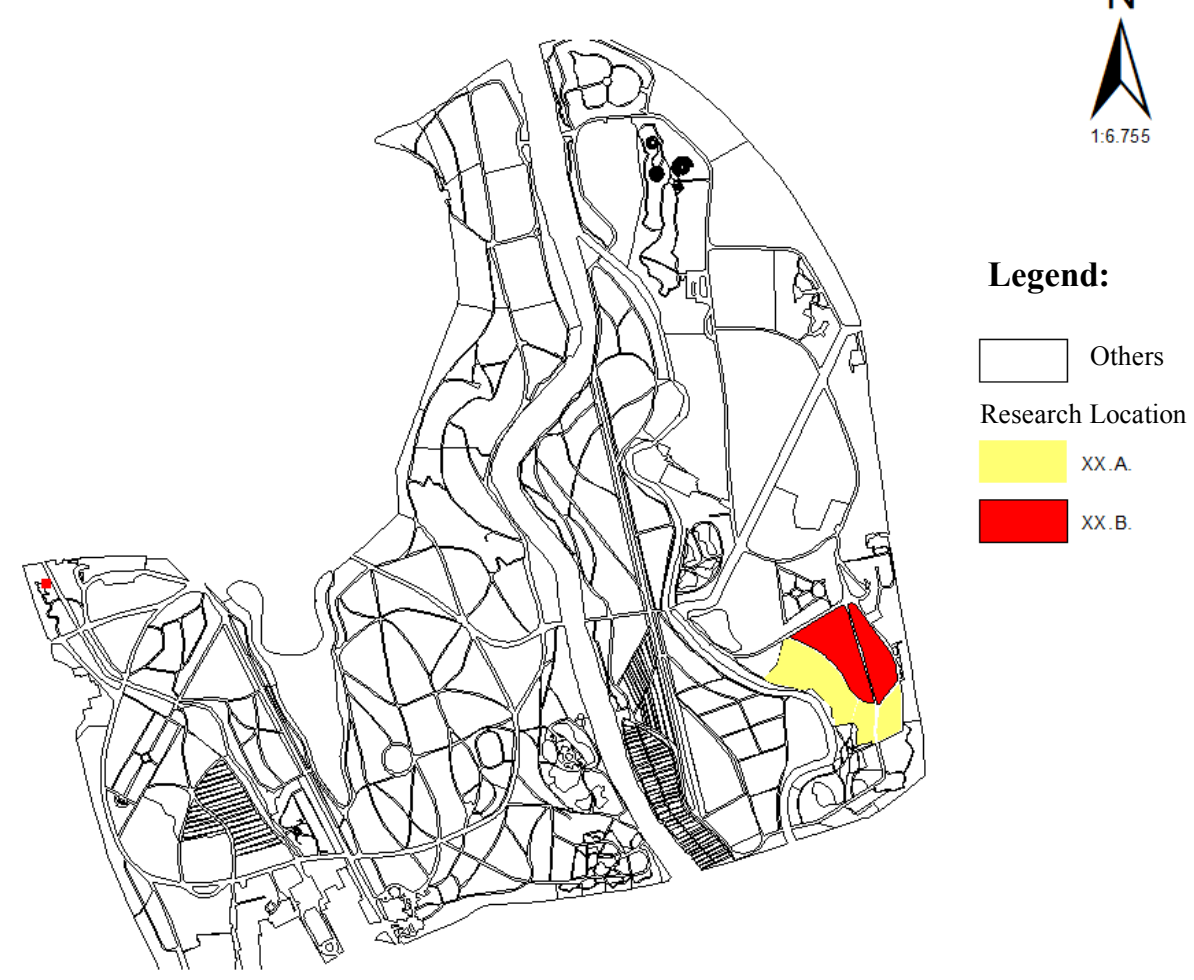

Fig. 1. Research location for the tree health monitoring of Lauraceae in Bogor Botanic Gardens. 
Table 1. The Lauraceae collections in XX.A and XX.B

\begin{tabular}{|c|c|c|c|}
\hline No & Species Name & Collection Number & Planting Year \\
\hline 1 & Endiandra macrophylla (Blume) Boerl. & XX.B.209 & 2007 \\
\hline 2 & Neolitsea cassiifolia (Blume) Merr. & XX.B.276 & 2018 \\
\hline 3 & Endiandra sp. & XX.B.239 & 1913 \\
\hline 4 & Eusideroxylon zwageri Teijsm. \& Binn. & XX.B.231 & 2012 \\
\hline 5 & Cryptocarya sp. & XX.B.278 & 2018 \\
\hline 6 & lseodaphnopsis andersonii (King ex Hook.f.) H.W.Li \& J.Li & XX.B.251 & 2015 \\
\hline 7 & lseodaphnopsis andersonii (King ex Hook.f.) H.W.Li \& J.Li & XX.B.251A & 2015 \\
\hline 8 & lseodaphnopsis andersonii (King ex Hook.f.) H.W.Li \& J.Li & XX.B.251B & 2015 \\
\hline 9 & Dehaasia sumatrana Kosterm. & XX.B.252 & 2015 \\
\hline 10 & Dehaasia sumatrana Kosterm. & XX.B.252A & 2015 \\
\hline 11 & Dehaasia sumatrana Kosterm. & XX.B.252B & 2015 \\
\hline 12 & Cinnamomum celebicum Miq. & XX.B.253 & 2015 \\
\hline 13 & Cinnamomum burmanni (Nees \& T.Nees) Blume & XX.B.254 & 2015 \\
\hline 14 & Phoebe grandis (Nees) Merr. & XX.B.92 & 1978 \\
\hline 15 & Cinnamomum burmanni (Nees \& T.Nees) Blume & XX.B.254A & 2015 \\
\hline 16 & Litsea glutinosa (Lour.) C.B.Rob & XX.B.25 & 1941 \\
\hline 17 & Beilschmiedia sp. & XX.B.258B & 2015 \\
\hline 18 & Beilschmiedia sp. & XX.B.258A & 2015 \\
\hline 19 & Beilschmiedia sp. & XX.B.258 & 2015 \\
\hline 20 & Litsea firma (Blume) Hook.f. & XX.B.257A & 2015 \\
\hline 21 & Litsea firma (Blume) Hook.f. & XX.B. 257 & 2015 \\
\hline 22 & Litsea sp. & XX.B.256A & 2015 \\
\hline 23 & Litsea sp. & XX.B.256 & 2015 \\
\hline 24 & Cryptocarya densiflora Blume & XX.B.221 & 2009 \\
\hline 25 & Cryptocarya ferrea Blume & XX.B.222 & 2009 \\
\hline 26 & Alseodaphne elongata (Blume) Kosterm. & XX.B.219 & 2009 \\
\hline 27 & Neolitsea cassiifolia (Blume) Merr. & XX.B.217 & 2009 \\
\hline 28 & Dehaasia incrassata (Jack) Nees & XX.B.220 & 2009 \\
\hline 29 & Beilschmiedia lucidula (Miq.) Kosterm. & XX.B.223 & 2009 \\
\hline 30 & Cryptocarya nitens (Blume) Koord. \& Valeton & XX.B.59 & 1971 \\
\hline 31 & Litsea glutinosa (Lour.) C.B.Rob & XX.B.62 & 1972 \\
\hline 32 & Litsea glutinosa (Lour.) C.B.Rob & XX.B.62A & 1972 \\
\hline 33 & Dehaasia caesia Blume & XX.B.232 & 2012 \\
\hline 34 & Cinnamomum javanicum Blume & XX.B.235 & 2012 \\
\hline 35 & Neolitsea cassia (L.) Kosterm & XX.B.233 & 2012 \\
\hline 36 & Litsea sp. & XX.B.206 & 2007 \\
\hline 37 & Dehaasia caesia Blume & XX.B.248 & 2014 \\
\hline 38 & Dehaasia caesia Blume & XX.B.248A & 2014 \\
\hline 39 & Lauraceae & XX.B.262 & 2016 \\
\hline 40 & Neolitsea cassia (L.) Kosterm. & XX.B.191 & 2004 \\
\hline 41 & Neolitsea cassia (L.) Kosterm. & XX.B.192 & 2004 \\
\hline 42 & Cryptocarya costata Blume & XX.B.194 & 2006 \\
\hline 43 & Litsea sp. & XX.B. 170 & 2001 \\
\hline 44 & Litsea sp. & XX.B.170A & 2001 \\
\hline 45 & Cryptocarya sp. & XX.B.72 & 1973 \\
\hline
\end{tabular}




\begin{tabular}{|c|c|c|c|}
\hline No & Species Name & Collection Number & Planting Year \\
\hline 46 & Cinnamomum sp. & XX.B.149 & 1995 \\
\hline 47 & Beilschmiedia sp. & XX.B.116 & 2004 \\
\hline 48 & Cinnamomum burmanni (Nees \& T. Nees) Blume & XX.B.142 & 1992 \\
\hline 49 & Neolitsea cassiifolia (Blume) Merr. & XX.B.33 & 1960 \\
\hline 50 & Cryptocarya nitens (Blume) Koord. \& Valeton & XX.B.47 & 1965 \\
\hline 51 & Cryptocarya nitens (Blume) Koord. \& Valeton & XX.B.47A & 1965 \\
\hline 52 & Litsea umbellata (Lours.) Merr. & XX.B.67 & 1973 \\
\hline 53 & Litsea sp. & XX.B.244 & 2014 \\
\hline 54 & Litsea sp. & XX.B.244A & 2014 \\
\hline 55 & Litsea sp. & XX.B.244B & 2014 \\
\hline 56 & Endiandra rubenscens (Blume) Miq. & XX.B.247 & 2014 \\
\hline 57 & Cryptocarya elliptifolia Merr. & XX.B.226 & 2010 \\
\hline 58 & Neolitsea sp. & XX.B.249 & 2014 \\
\hline 59 & Actinodaphne macrophylla (Blume) Nees & XX.B.243 & 2014 \\
\hline 60 & Cryptocarya diversifolia Blume & XX.B.172 & 2002 \\
\hline 61 & Cananga odorata (Lam.) Hook.f. \& Thomson & XX.B.20b & 2017 \\
\hline 62 & Cananga odorata (Lam.) Hook.f. \& Thomson & XX.B.20c & 2017 \\
\hline 63 & Cananga odorata (Lam.) Hook.f. \& Thomson & XX.B.20 & 1992 \\
\hline 64 & Actinodaphne macrophylla (Blume) Nees & XX.B.143 & 1976 \\
\hline 65 & Litsea firma (Blume) Hook.f. & XX.B.144 & 1992 \\
\hline 66 & Machilus yunnanensis Lecomte & XX.B.89 & 1976 \\
\hline 67 & Litsea sp. & XX.B.124a & 2007 \\
\hline 68 & Grevillea papuana Diels & XX.B.148 & 2007 \\
\hline 69 & Neolitsea cassia (L.) Kosterm. & XX.B.146 & 1995 \\
\hline 70 & Persea sp. & XX.B.137 & 1995 \\
\hline 71 & Cryptocarya diversifolia Blume & XX.B.12 & 1995 \\
\hline 72 & Litsea glutinosa (Lour.) C.B.Rob. & XX.B.40a & 1976 \\
\hline 73 & Litsea monopetala (Roxb.) Pers. & XX.B.269 & 2008 \\
\hline 74 & Litsea monopetala (Roxb.) Pers. & XX.B.270 & 2017 \\
\hline 75 & Cryptocarya massoy (Oken) Kosterm. & XX.B.141 & 1992 \\
\hline 76 & Litsea firma (Blume) Hook.f. & XX.B.82 & 2017 \\
\hline 77 & Premna sp. & XX.B.99 & 2017 \\
\hline 78 & Premna sp. & XX.B.99a & 2017 \\
\hline 79 & Cinnamomum sintoc Blume & XX.B.202 & 2007 \\
\hline 80 & Cinnamomum sintoc Blume & XX.B.202a & 2007 \\
\hline 81 & Actinodaphne sp. & XX.B.152a & 1995 \\
\hline 82 & Cryptocarya sp. & XX.B.156 & 1995 \\
\hline 83 & Cryptocarya sp & XX.B. 150 & 1995 \\
\hline 84 & Beilschmiedia lucidula (Miq.) Kosterm. & XX.B.83 & 1976 \\
\hline 85 & Beilschmiedia lucidula (Miq.) Kosterm. & XX.B.214 & 2008 \\
\hline 86 & Cinnamomum camphora (L.) J.Presl & XX.B.41 & 1991 \\
\hline 87 & Litsea glutinosa (Lour.) C.B.Rob. & XX. B.40 & 1960 \\
\hline 88 & Neolitsea cassia (L.) Kosterm. & XX.A.144 & 2017 \\
\hline 89 & Neolitsea cassia (L.) Kosterm. & XX.A.144A & 2017 \\
\hline 90 & Neolitsea cassia (L.) Kosterm. & XX.A.144B & 2017 \\
\hline 91 & Cryptocarya sp. & XX.A.136 & 2017 \\
\hline
\end{tabular}




\begin{tabular}{|c|c|c|c|}
\hline No & Species Name & Collection Number & Planting Year \\
\hline 92 & Cryptocarya sp. & XX.A.136A & 2017 \\
\hline 93 & Cryptocarya sp. & XX.A.136B & 2017 \\
\hline 94 & Cryptocarya sp. & XX.A.137 & 2017 \\
\hline 95 & Cryptocarya sp. & XX.A.137A & 2017 \\
\hline 96 & Cryptocarya sp. & XX.A.137B & 2017 \\
\hline 97 & Actinodaphne glomerata (Blume) Nees & XX.A.129 & 2017 \\
\hline 98 & Actinodaphne glomerata (Blume) Nees & XX.A.129A & 2017 \\
\hline 99 & Actinodaphne glomerata (Blume) Nees & XX.A.129B & 2017 \\
\hline 100 & Actinodaphne glomerata (Blume) Nees & XX.A.129C & 2017 \\
\hline 101 & Eusideroxylon zwageri Teijs. \& Binn & XX.A.134 & 2017 \\
\hline 102 & Dehaasia sumatrana Kosterm & XX.A. 138 & 2017 \\
\hline 103 & Dehaasia incrassata (Jack) Kostern & XX.A. 140 & 2017 \\
\hline 104 & Beilschmiedia kunstleri Gamble & XX.A.124 & 2005 \\
\hline 105 & Beilschmiedia kunstleri Gamble & XX.A.124A & 2005 \\
\hline 106 & Eusideroxylon zwageri Teijs. \& Binn & XX.A.93 & 1984 \\
\hline 107 & Eusideroxylon zwageri Teijs. \& Binn & XX.A.18 & 1930 \\
\hline 108 & Litsea sp. & XX.A.112 & 2002 \\
\hline 109 & Litsea sp. & XX.A.112A & 2002 \\
\hline 110 & Endiandra macrophylla (Blume) Boerl & XX.A.109 & 1900 \\
\hline 111 & Endiandra macrophylla (Blume) Boerl & XX.A.109A & 1900 \\
\hline 112 & Cryptocarya crassinervia miq & XX.A.102 & 1998 \\
\hline 113 & Cryptocarya nitens Koord. \& Valeton & XX.A.105 & 1998 \\
\hline 114 & Cinnamomum sp. & XX.A.104 & 1998 \\
\hline 115 & Endiandra macrophylla (Blume) Boerl & XX.A.103 & 1998 \\
\hline 116 & Endiandra macrophylla (Blume) Boerl & XX.A.103A & 1998 \\
\hline 117 & Endiandra macrophylla (Blume) Boerl & XX.A.103B & 1998 \\
\hline 118 & Cinnamomum iners Reinw. ex Blume, Bijdr. & XX.A.99 & 1998 \\
\hline 119 & Cinnamomum iners Reinw. ex Blume, Bijdr. & XX.A.99A & 1998 \\
\hline 120 & Litsea oppositifolia LS Gibbs & XX.A.107 & 1998 \\
\hline 121 & Litsea oppositifolia LS Gibbs & XX.A.107A & 1998 \\
\hline 122 & Endiandra macrophylla (Blume) Boerl. & XX.A.55 & 1975 \\
\hline 123 & Lindera aggregata $(\mathrm{Sims})$ Kosterm. & XX.A.126 & 2008 \\
\hline 124 & Lindera aggregata $(\mathrm{Sims})$ Kosterm. & XX.A.126 A & 2008 \\
\hline 125 & Lindera aggregata (Sims) Kosterm. & XX.A.126 B & 2008 \\
\hline 126 & Lindera aggregata (Sims) Kosterm. & XX.A.126 C & 2008 \\
\hline 127 & Litsea sp. & XX.A.133 & 2017 \\
\hline 128 & Litsea firma (Blume) Hook.f. & XX.A.132 & 2017 \\
\hline 129 & Litsea $\mathrm{sp}$ & XX.A.131 & 2017 \\
\hline 130 & Cinnamomum camphora (L.) J.Presl & XX.A.62A & 1965 \\
\hline 131 & Litsea garciae S.Vidal & XX.A.122 & 2005 \\
\hline 132 & Cinnamomum camphora (L.) J.Presl & XX.A.62 & 1965 \\
\hline 133 & Beilschmiedia sp. & XX.A. 128 & 2017 \\
\hline 134 & Beilschmiedia emarginata (Meisn.) & XX.A.127 & 2017 \\
\hline 135 & Cinnamomum celebicum Miq. & XX.A.141 & 2017 \\
\hline 136 & Cinnamomum celebicum Miq. & XX.A.142 & 2017 \\
\hline 137 & Litsea garciae S.Vidal & XX.A.130 & 2017 \\
\hline
\end{tabular}




\begin{tabular}{lllc}
\hline No & \multicolumn{1}{c}{ Species Name } & Collection Number & Planting Year \\
\hline 138 & Litsea garciae S.Vidal & XX.A.130A & 2017 \\
139 & Dehaasia incrassata (Jack) Nees & XX.A.139 & 2017 \\
140 & Dehaasia incrassata (Jack) Nees & XX.A.139A & 2017 \\
141 & Litsea garciae S.Vidal & XX.A.123 & 2005 \\
142 & Cinnamomum iners (Reinw. ex Nees \& T.Nees) Blume & XX.A.44.A & 1930 \\
143 & Actinodaphne glabra Blume & XX.A.115A & 2004 \\
144 & Actinodaphne glabra Blume & XX.A.115 & 2004 \\
145 & Dehaasia incrassata (Jack) Nees & XX.A.119 & 2004 \\
146 & Dehaasia incrassata (Jack) Nees & XX.A.120 & 2004 \\
147 & Dehaasia incrassata (Jack) Nees & XX.A.120A & 2004 \\
148 & Nectandra angustifolia (Schrad.) Nees \& Mart. & XX.A.96 & 1985 \\
149 & Litsea glutinosa (Lour.) C.B.Rob. & XX.A.75A & 1972 \\
\hline
\end{tabular}

\subsection{Data Collection}

The data was collected in the form of primary and secondary data. Primary data were obtained through direct observation and grouped into four age groups based on year of planting (YP), i.e.: (1) 0-15 years, (2) 16-30 years, (3) 31-60 years, and (4) $\geq 61$ years. The parameters that were observed directly consisted of tree species and damage conditions. The types of damage observed in detail were the signs and symptoms that appear to determine the cause of the damage caused by physical factors (humans), fungi, and insects. If a sign of damage was found in insect attacks, the type of insect was identified.

The tree damage value variable comprises the damage location, type, and severity, categorized through coding and quality scores $(\mathrm{x})$. The coding and quality scores for type $(\mathrm{x})$ and severity (z) are shown in Table 2. Secondary data were taken from references to studies related to tree health previously carried out in BBG.

Table 2. Coding and quality scores for each location, type of damage, and severity (Mangold 1997)

\begin{tabular}{cccccc}
\hline $\begin{array}{c}\text { Damage } \\
\text { location } \\
\text { code }\end{array}$ & $\begin{array}{c}\text { Weight value of } \\
\text { damage locations } \\
(\mathbf{x})\end{array}$ & $\begin{array}{c}\text { Damage type } \\
\text { code }\end{array}$ & $\begin{array}{c}\text { Weight value of } \\
\text { damage types } \\
(\mathbf{y})\end{array}$ & $\begin{array}{c}\text { Damage } \\
\text { severity } \\
\text { code }\end{array}$ & $\begin{array}{c}\text { Weight value of } \\
\text { damage severity } \\
(\mathbf{z})\end{array}$ \\
\hline 0 & 0 & 01,26 & 1,9 & 0 & 1 \\
1 & 2 & 02 & 1,7 & 1 & 1,1 \\
2 & 2 & 03,04 & 1,5 & 2 & 1,2 \\
3 & 1,8 & 05 & 2 & 3 & 1,3 \\
4 & 1,8 & 06 & 1,5 & 4 & 1,4 \\
5 & 1,6 & 11 & 2 & 5 & 1,5 \\
6 & 1,2 & 12 & 1,6 & 6 & 1,6 \\
7 & 1 & 13,20 & 1,5 & 7 & 1,7 \\
8 & 1 & 21 & 1,3 & 8 & 1,8 \\
9 & 1 & $22,23,24,25,31$ & 1 & 9 & 1,9 \\
\hline
\end{tabular}

Notes: Damage location: $1=$ root, $2=$ roots and rootstock, $3=$ lower stem, $4=$ stem bottom and top, $5=$ stem top, 6 $=$ head trunk, $7=$ branch, $8=$ buds and shoots, $9=$ leaf; Damage types: $01=$ cancer, $02=$ konk, $03=$ open wound, 04 $=$ resinosis/gummosis, $05=$ broken stem, $06=$ termite nest, $11=$ broken stem or root, $12=$ brum on root or stem, 13 = broken/ dead root, 20 = liana, $21=$ loss of dominant end dead end, $22=$ broken or dead branch, $23=$ excessive branching or brum, $24=$ leaf buds or damaged shoots, $25=$ leaves change color, $31=$ others; Damage severity: $0=0$ $9 \%, 1=10-19 \%, 2=20-29 \%, 3=30-39 \%, 4=40-49 \%, 5=50-59 \%, 6=60-69 \%, 7=70-79 \%, 8=80-89 \%, 9=90-$ $99 \%$. 


\subsection{Data Analysis}

Tree damage data processing is classified based on the value of the Tree Damage Index (TDI). There are four categories of tree damage based on the TDI calculation, namely: (1) healthy $(0-5),(2)$ light damage (6-10), (3) moderate damage (11-15), and (4) severe damage $(\geq 16)$.

$$
\mathrm{TDI}=\sum_{i=1}^{n}(x i . y i . z i)
$$

where $x i, y i$, and $z i$ are the weight value of the location, type, and severity of tree damage, respectively.

\section{Results and Discussion}

\subsection{Lauraceae Health Condition}

The tree collection of the Lauraceae in the Bogor Botanic Gardens (BBG) consists of 17 genera, 84 species, and 860 collection trees (Ariati et al. 2019). The total tree collection of the Lauraceae that were planted in plots XX.A and XX.B is 149 trees. From the 149 Lauraceae collections, 36 trees have not been identified, while the remaining collection trees include 45 species that have been identified. In general, the Lauraceae collections has a healthy condition (Fig 2a). In addition, it was also known that the distribution of age groups based on the year of planting (AYP) of the Lauraceae in the plots was dominated by species with AYP of 0-15 years (Fig. 2b).

In detail, the number of collection trees in healthy condition was 103 trees, while those damaged were 34 trees. There were 9 trees lightly damaged, 10 trees moderately damaged, 15 trees heavily damaged, and 12 trees dead. Interestingly, the number of damaged trees was reasonably distributed in each AYP (Fig. 2b). However, the Tree Damage Index (TDI) calculation results show that the health condition of the Lauraceae is dominated by healthy collections (TDI 0-5).

In AYP 0-15 years, the number of collection trees that were not damaged (TMK) and damaged (MK) was almost the same, while in AYP 16-30 years, 31-60 years, and 61 years and over showed the number of collection trees that experienced damage was higher than the collection tree that was not damaged. The number of damaged trees was relatively high in the AYP 16-60 years. The damage in the early-middle AYP class causes many collection trees not to survive and eventually die. This condition causes the number of reports of dead collections of the Lauraceae from 1999-2018 to have the highest number in the BBG, as many as 155 trees (Setyanti et al. 2020).
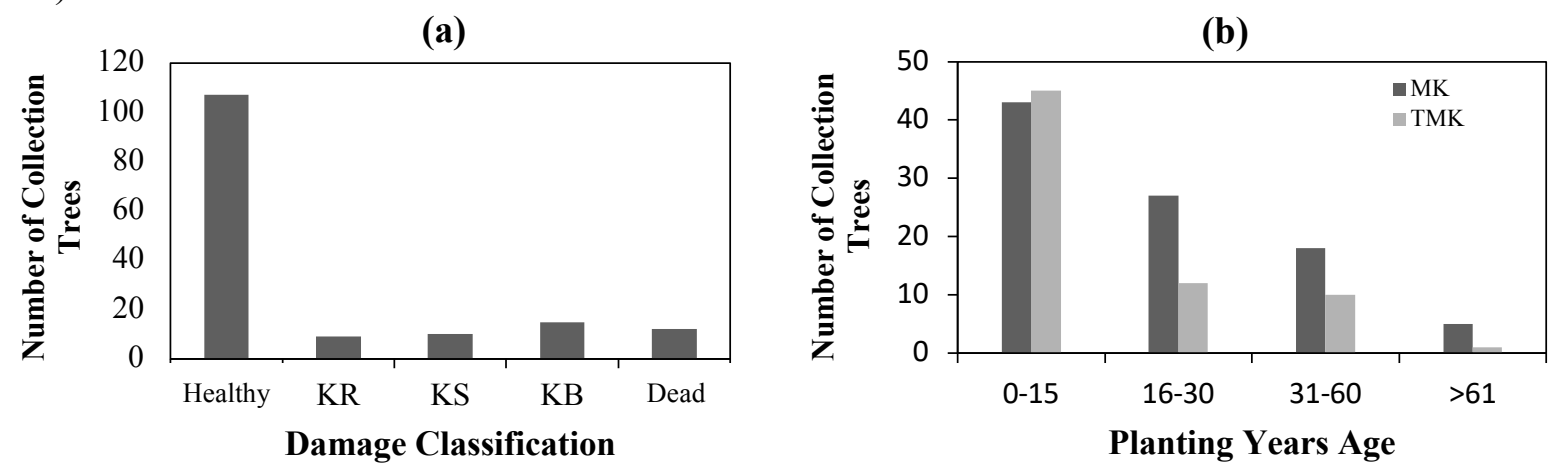

Fig. 2. (a) Health classification of the Lauraceae (KR=Mild Damage; $K S=$ Medium Damage; $\mathrm{KB}=$ Heavy Damage); (b) the ratio of the age of the year of planting to the health condition of the Lauraceae in the Bogor Botanic Gardens ( $\mathrm{MK}=$ Damaged; TMK=No damage $)$. 


\subsection{Damage Location}

In general, the damages of a tree occured in the stem and crown (Pertiwi et al. 2019). The damage of Lauraceae collections in BBG was generally found in the stems and crowns. The observations results showed 63 trees damaged in the trunk, 51 trees damaged in the crown branches, and 13 trees experienced damages in the roots (Fig. 3a). The frequency of damage each tree varies. 45 tree experienced damages in a single location, 32 trees experienced damages in two location, and 6 trees had damages in 3 location at the same time (Fig. 3b).

(a)

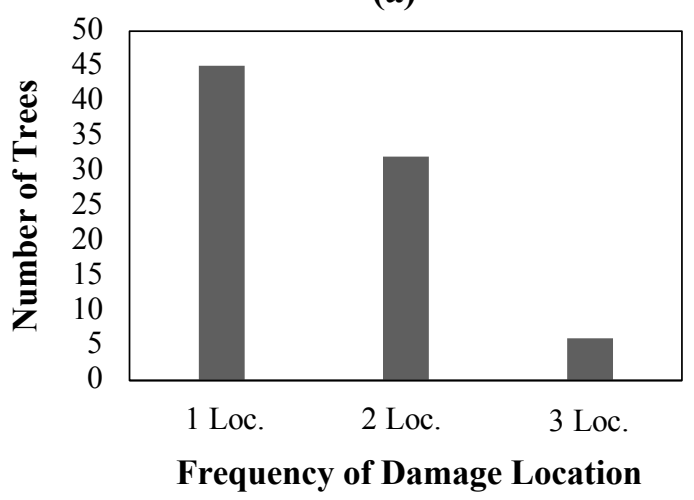

(b)

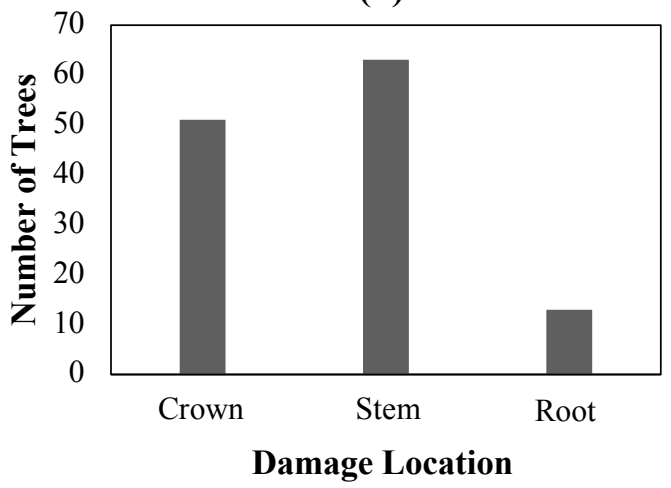

Fig. 3. Description of the damage location of the Lauraceae in the Bogor Botanic Gardens:

(a) frequency of damage location and (b) damage location.

Tsani and Safe'i (2018) revealed that the dominance of the location of damage in stem was also found in trees located at the Way Kambas National Park Training Center. However, stem damages generally occur in the wounds caused by friction from animals, such as wild boars and elephants, which is different from the cause of stem damage in BBG. The results of observations at BBG showed that stem damages that occurred in the Lauraceae collection was initiated by the attack of borers and cracks in the main branches (Fig. 4a and Fig 4b). Based on observations, these cracks will usually cause the crown area dry out and die. It is presumably because these cracks disrupt the phloem tissue so that the nutrient supply path to the crown is disturbed. In some species of the Lauraceae, resin/sap will come out when experiencing symptoms of damage to the stem, which is thought to be a form of self-defense (Fig. 4c). However, in general, the location of the damage to these stems is still relatively light (0-19\%).

Damage to the Lauraceae collection at the two locations observed was dominated by the crown and stem locations. These conditions will disrupt physiological processes, especially in the process of photosynthesis and supply of nutrients (Pokorny 1992; Sumardi and Widyastuti 2002), so that the direct impact is a decrease in plant resistance to disease (disease resistance).

The highest types of damage were broken or dead branch damage (38\%) and other damage categories (28\%), such as peeling bark and cracked stems (Fig. 5a). The severity of the damage that occurred in the Lauraceae showed that the dominant severity was mild (0-19\%) and decreased in the following classification at the severity of 20-29\%, 30-39\%, and 40-49\% (Fig. 5b). The score of the severity level is still relatively standard, but we need to be aware of the occurrence of the severity level that continues in the future. 

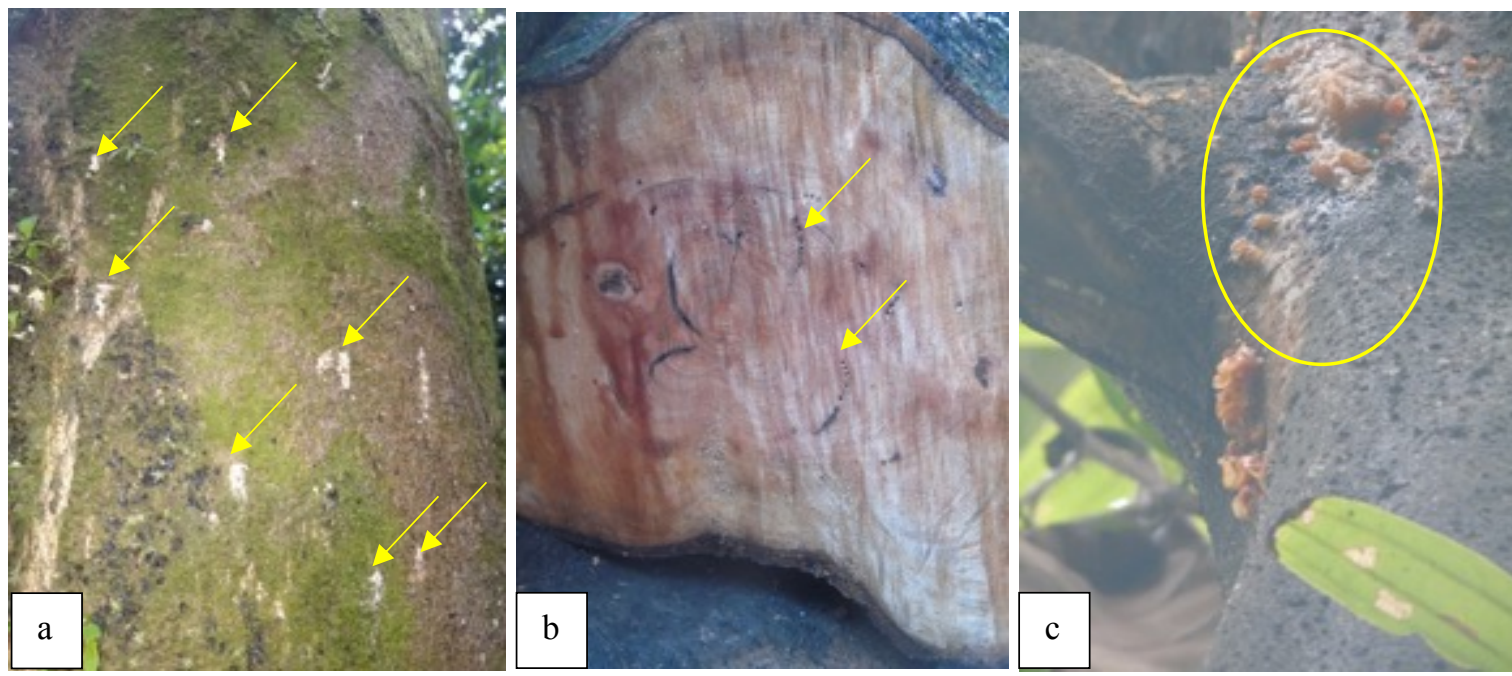

Fig. 4. (a) Traces of attack by borers (yellow arrows), (b) traces of borer insects after the collection died and were cut crosswise, (c) a form of self-defense from the Lauraceae by secreting resin.

Routine maintenance in the form of light pruning is a priority to reduce more severe damage. It is expected to be influenced by the age and height of the plant. The Lauraceae in the BBG is dominated by the relatively young age of collection trees, so many collections are still healthy.

(a)

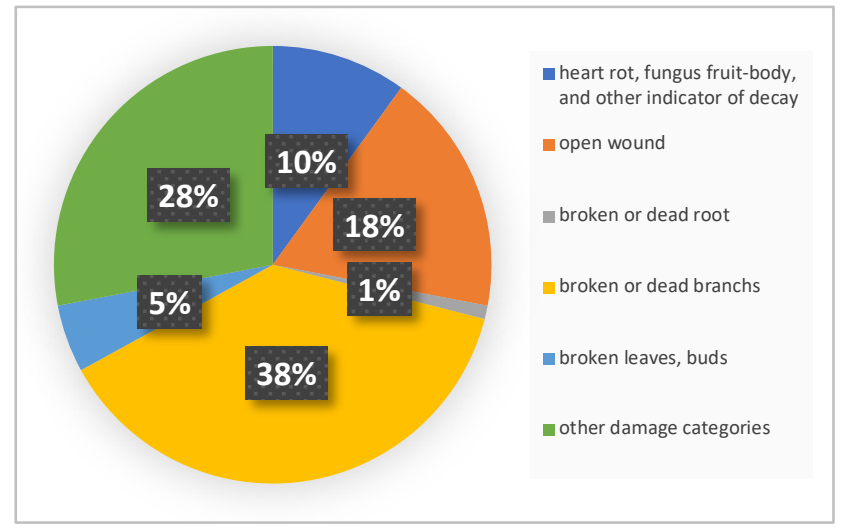

(b)

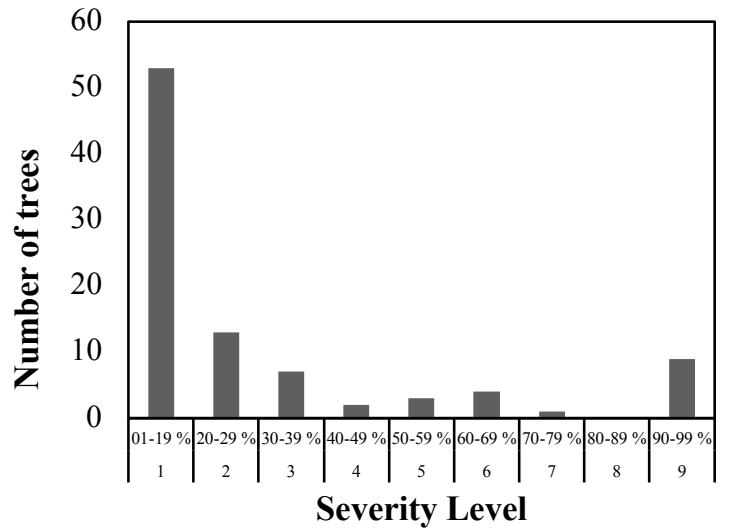

Fig. 5. (a) Damage type, and (b) severity level of the Lauraceae in the Bogor Botanic Gardens.

\subsection{Type of Damage}

Tree health is strongly influenced by biotic and abiotic factors (Pertiwi et al. 2019). Collection maintenance is an effort of human intervention to improve the quality collections is included in abiotic factors. Collection maintenance can affect tree health, such as light pruning. Another abiotic factor is the weather, such as rain, wind, and lightning, which can cause the collection to fall and die. Another abiotic factor is the unmet nutritional needs of the collection. Lack of nutrients will cause trees to become vulnerable to plant-disturbing insects (Abimanyu et al. 2019; Susilowati et al. 2018; Tsani and Safe'i 2018). Biotic factors that usually reduce the level of tree health are the attack of plant-disturbing organisms such as pests (for example, termites and stem borer insects), diseases (for example, attacks by fungi and other microorganisms), and weeds (Abimanyu et al. 2019; Helmanto et al. 2018; Pribadi 2010; Safe'i et al. 2020). 
Insects that are often found in the Lauraceae in BBG are stem borers. Visual observation of the damage found in the Lauraceae collections in BBG showed insect traces in the form of small holes on the stems and traces of sawdust (Fig. 4a). The age of Lauraceae collections, which is still relatively young, can attract and increase the attack of stem borer insects. Affected plants will be short and have many branches when recovered (Kendra et al. 2013; Wikardi and Wahyono 1991). It follows the symptoms found in the collection trees in the Lauraceae plot. Therefore, appropriate efforts are needed to reduce the level of insect attack on the Lauraceae collections in BBG, such as by installing wooden traps. (FAO 2011).

Dead or dry branches (Fig. 6a) and broken branches on the upper branch or top section (Fig. 6b) were common in the Lauraceae tree collections. Dead branches and broken upper branches are caused by shoot-sucking insects from the Lepidoptera nation (Wikardi and Wahyono 1991). In addition to the conditions previously mentioned, there were also infected trees and overgrown with Ganoderma fungal bodies (Fig. 6c). The fungus indicates that there is a suspicion that further weathering has occurred in the main stem. This is also often found in several hosts of the Ganoderma fungus, which have many hosts, especially for woody plant species (Susanto et al. 2013). Ganoderma fungus are also commonly found in the Yellow Nature Tourism Park on rotting wood. Their presence is detrimental to tree trunks because they absorb nutrients from their hosts (Harahap et al. 2017; Sankaran et al. 2005).
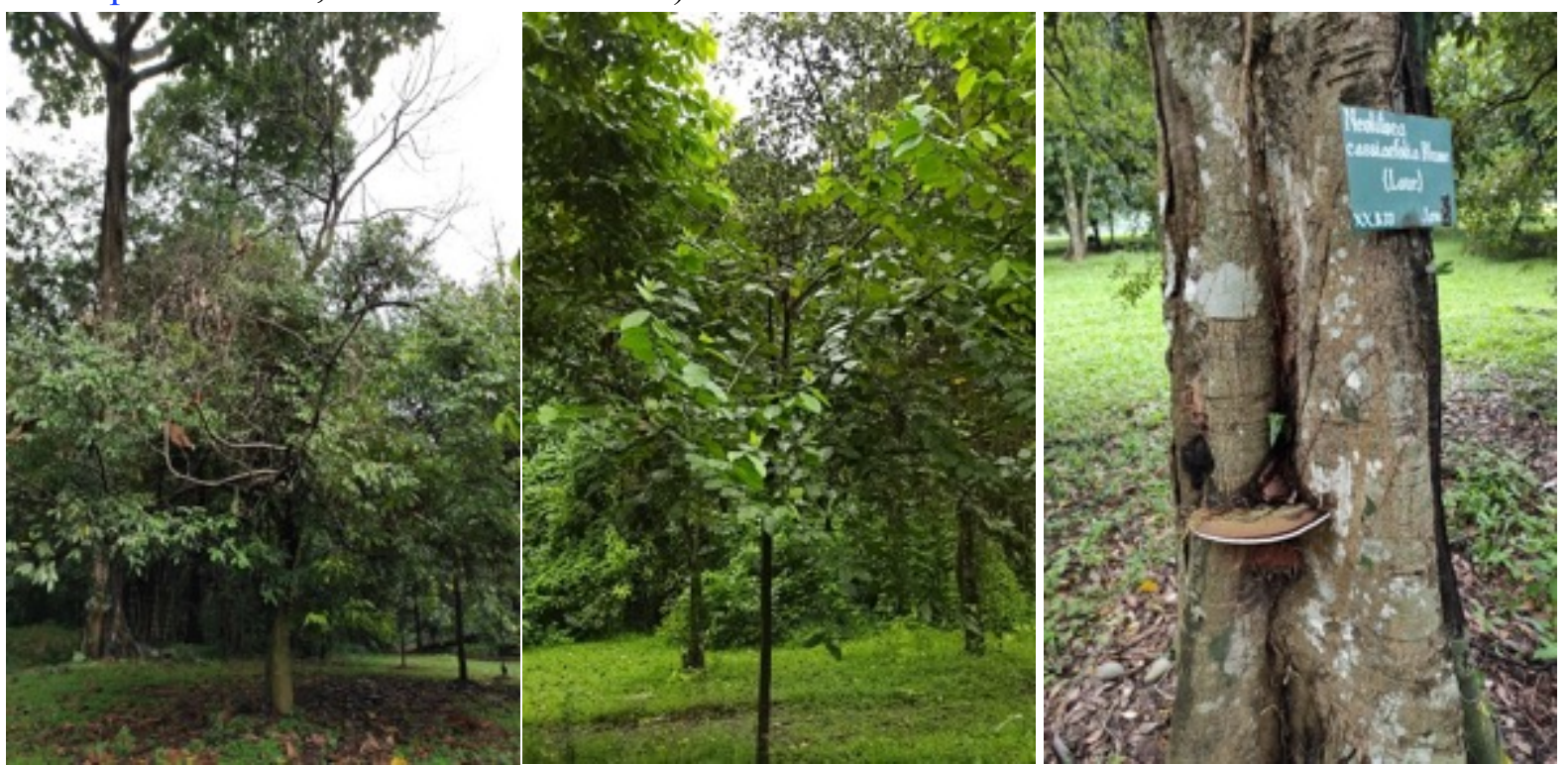

Fig. 6. Damage typr of the Lauraceae in the Bogor Botanic Gardens: (a) damage to some dried branches; (b) damage to the top of the header; (c) stem damage due to Ganoderma fungus.

The frequency of symptoms and damage that leads to sudden death in the Lauraceae also indicates the possibility of fungal diseases associated with borer insects. Several collections experienced symptoms of leaf wilting in part or all of the branches and symptoms of stem borer on the same tree, which caused symptoms of drought and tree death in a short time. The species of borer that is thought to be the ambrosia beetle from the subfamily of Scolytinae or Platypodinae is attracted to the ethanol produced by stressed or sick Lauraceae trees. However, the ambrosia redbay beetle is attracted by the specific essential oil produced by several species of Lauraceae even though the tree is healthy (Olatinwo et al. 2021). The ambrosia beetle mainly carries fungal pathogens that simultaneously infect trees when the ambrosia beetle gnaws on the tree's xylem. 
One of the phenomenal wilt diseases that attack Lauraceae trees with an association mechanism with borer insects is laurel wilt. The laurel wilt is a vascular disease caused by the fungus Raffaelea lauricola transmitted by an invasive vector, Ambrosia redbay bettle (Xyleborus glabratus) from the subfamily of Scolytinae (Kendra et al. 2013; Olatinwo et al. 2021). This disease so far only affects members of the Lauraceae. Symptoms caused by the disease are a change in the color of the wood sap to blackish in the form of small strokes which later infect the whole xylem tissue. The laurel wilt infection is followed by wilted leaves and shoots and dieback branches. The reddish or purplish-brown color on dead leaves can remain visible for more than a year after the leaves die. The whole tree will die within weeks to months of infection (Kendra et al. 2013; Olatinwo et al. 2021; Spence et al. 2013).

In the southeastern United States, laurel wilt has become a significant problem since its introduction to America in 2002. The disease affects redbay (Persea borbonia) and sassafras (Sassafras albidum) trees. Laurel wilt also affects the production of avocado trees (Persea americana) and is thought to potentially attack other native species of the Lauraceae (Olatinwo et al. 2021; Ploetz et al. 2017). The origin of Xyleborus glabratus and Raffaelea lauricola is known to come from Southeast Asia. However, the symbiosis of the two is found in warm and humid areas of Asian countries (India, China, Vietnam, Japan, Taiwan, and others) and invades the southeastern United States. The Ambrosia Redbay beetle is only known to attack Lauraceae in North America. Nevertheless, in Asia, this beetle is also associated with species from the Dipterocarpaceae, Fagaceae, Theaceae, Pinaceae, and Fabaceae families (Kendra et al. 2013; Olatinwo et al. 2021; Spence et al. 2013).

In Indonesia, the existence of this disease has not been well documented. Rodearman's (2017) observations regarding the ambrosia beetle on Albizia chinensis in East Java and Haneda et al. (2020) regarding the diversity of borers on Hopea odorata in West Java did not show the presence of the Ambrosia beetle. Seeing the symptoms, especially wilting and sudden dryness in the collections of the Lauraceae in BBG, it is necessary to carry out further observations regarding the possibility of disease attacks resembling laurel wilt. According to Olatinwo et al. (2021), the appropriate action in tackling the widespread spread of the attack is to implement an integrated pest management strategy, such as implementing good sanitation to suppress insect populations, applying chemical and biological controls, and killing host trees.

\section{Conclusions}

The tree health of the Lauraceae collections in the Bogor Botanic Gardens is generally in a healthy condition with a Tree Damage Index (TDI) of 0-5. The total number of trees collected by the Lauraceae in plots XX.A and XX.B are 149 trees with 103 healthy, 9 lightly damaged, 10 moderately damaged, 15 heavily damaged, and $12 \mathrm{dead}$. The most common locations of damage were found in the stems and crowns. More comprehensive research on plant pests and diseases is needed to mitigate damage to the Lauraceae collections in the Bogor Botanic Gardens.

\section{Acknowledgments}

The authors would like to thank the Head of the Research Center for Plant Conservation and Botanical Gardens of the Indonesian Institute of Sciences (LIPI) who has given permission and 
support for this research. We also thank the Internship Students from Universitas Siperbangsa Karawang (UNSIKA) who have helped Tim Analis Kesehatan Pohon Kebun Raya Bogor.

\section{References}

Abimanyu, B., Safe'i, R., and Hidayat, W. 2019. Aplikasi Metode Forest Health Monitoring dalam Penilaian Kerusakan Pohon di Hutan Kota Metro. Jurnal Sylva Lestari 7(3): 289-298. DOI: 10.23960/js137289-298

Ariati, S. R., Astuti, R. S., Supriyatna, I., Yuswandi, A. Y., Setiawan, A., Saftaningsih, D., and Pribadi, D. O. 2019. An Alphabetical List of Plant Species Cultivated in the Bogor Botanic Garden. Bogor: Center for Plant Conservation Botanic Garden, Bogor.

FAO. 2011. Guide to Implementation of Phytosanitary Standards in Forestry. FAO Forestry Paper No. 164. Rome, Italy.

Haneda, N. F., Furqan, M., and Suheri, M. 2020. Stem Borer Insects on Hopea odorata in Bogor, West Java, Indonesia. Biodiversitas 21(11): 5308-5316.

Harahap, L. C., Syamsi, F., and Efendi, Y. 2017. Inventarisasi Jamur Tingkat Tinggi (Basidiomycetes) Di Taman Wisata Alam Muka Kuning Batam. SIMBIOSA 6(2): 74-4. DOI: 10.33373/sim-bio.v6i2.1143

Helmanto, H., Kristiati, E., Wardhani, F.F., Zulkarnaen, R.N. and Rachmadiyanto, A.N. 2018, November. Tree health assessment of Agathis borneensis Warb. in Bogor Botanical Garden using arborsonic. In IOP Conference Series: Earth and Environmental Science (Vol. 203, No. 1, p. 012032). IOP Publishing.

Kendra, P. E., Montgomery, W. S., Niogret, J., and Epsky, N. D. 2013. An Uncertain Future for American Lauraceae: A Lethal Threat from Redbay Ambrosia Beetle and Laurel Wilt Disease (A Review). American Journal of Plant Sciences 4: 727-738. DOI: 10.4236/ajps.2013.43a092

Mangold, R. 1997. Forest Health Monitoring Field Methods Guide. USDA Forest Service, Washington D.C. 20090.

Olatinwo, R. O., Fraedrich, S. W., and Mayfield, A. E. 2021. Laurel Wilt: Current and Potential Impacts and Possibilities for Prevention and Management. Forests 12: 181. DOI: 10.3390/f12020181

Pertiwi, D., Safe'i, R., Kaskoyo, H., and Indriyanto, I. 2019. Identifikasi Tipe Kerusakan Pohon Menggunakan Metode Forest Health Monitoring (FHM). Perennial 15(1): 1-7. DOI: 10.24259/perennial.v15i1.6033

Ploetz, R. C., Konkol, J. L., Pérez-Martínez, J. M., and Fernandez, R. 2017. Management of Laurel Wilt of Avocado, Caused by Raffaelea lauricola. European Journal of Plant Pathology 149(1): 133-143. DOI: 10.1007/s10658-017-1173-1

Pokorny, J. D. 1992. Urban Tree Risk Management: A Community Guide to Program Design and Implementation. USDA Forest Service, Northeastern Area St, Paul, MN.

Pribadi, A. 2010. Serangan Hama dan Tingkat Kerusakan Daun Akibat Hama Defoliator pada Tegakan Jabon (Anthocephalus cadamba Miq.). Jurnal Penelitian Hutan dan Konservasi Alam 7(4): 451-458.

President Regulation. 2011. Peraturan Presiden No 93 Tahun 2011 tentang Kebun Raya . Indonesia.

Ramdhani, A. Y., and Fatimah, I. S. 2016. Studi Potensi Kanopi Pohon di Kebun Raya Bogor 
dalam Menyerap Emisi Karbondioksida dari Kendaraan Bermotor. Jurnal Lanskap Indonesia 5(1): 41-46.

Rodearman G, E. 2017. Keanekaragaman Kumbang Ambrosia pada Tanaman Sengon di Kota Batu, Jawa Timur. Skripsi. Program Studi Agroekoteknologi. Fakultas Pertanian, Universitas Brawijaya.

Safe'i, R., Kaskoyo, H., Darmawan, A., and Indriani, Y. 2020. Kajian Kesehatan Hutan dalam Pengelolaan Hutan Konservasi. ULIN: Jurnal Hutan Tropis 4(2): 70-76. DOI: 10.32522/ujht.v4i2.4323

Sankaran, K. V., Bridge, P. D., and Gokulapalan, C. 2005. Ganoderma Diseases of Perennial Crops in India - An overview. Mycopathologia 159: 143-152. DOI: 10.1007/s11046-004-4437-1

Setyanti, D., Nurhayati, and Pribadi, D. O. 2020. Mapping the Dynamics of Dead Trees Collection to Support Sustainable Landscape Management at Bogor Botanic Gardens. IOP Conference Series: Earth and Environmental Science 501: 012020. DOI: 10.1088/17551315/501/1/012020

Spence, D. J., Smith, J. A., Ploetz, R., Hulcr, J., and Stelinski, L. L. 2013. Effect of Chipping on Emergence of the Redbay Ambrosia Beetle (Coleoptera: Curculionidae: Scolytinae) and Recovery of the Laurel Wilt Pathogen from Infested Wood Chips. Journal of Economic Entomology 106(5): 2093-2100. DOI: 10.1603/EC13072

Sumardi, and Widyastuti, M. S. 2002. Dasar-Dasar Perlindungan Hutan. Gadjah Mada University Press. Yogyakarta.

Susanto, A., Prasetyo, A.E. and Wening, S. 2013. Laju Infeksi Ganoderma pada Empat Kelas Tekstur Tanah. Jurnal Fitopatologi Indonesia 9(2): 39-39.

Susilowati, A., Ahmad, A. G., Silalahi, V., and Rachmat, H. H. 2018. The Detection and Monitoring the Tree Health of Swietenia macrophylla in University of Sumatera Utara's (USU) Campus Area. IOP Conference Series: Earth and Environmental Science 203: 012028. DOI: $10.1088 / 1755-1315 / 203 / 1 / 012028$

Tsani, M. K., and Safe'i, R. 2018. Identifikasi Tingkat Kerusakan Tegakan pada Kawasan Pusat Pelatihan Gajah Taman Nasional Way Kambas. Jurnal Hutan Tropis 5(3): 215-221. DOI: 10.20527/jht.v5i3.4788

Wikardi, E., and Wahyono, T. 1991. Serangga-Serangga Perusak Tanaman Kayu Manis (Cinnamomum spp.) dan Musuh Alaminya. Buletin Penelitian Tanaman Rempah dan Obat 6(1): 20-26. DOI: 10.21082/bullittro.v6n1.1991.20-26 